\title{
The Implications of Tun Dr. Mahathir Mohamad's Leadership on Islamic Economic Development in Malaysia
}

\author{
Noor Husna Mohd Shafie*, Mohd Syakir Mohd Rosdi
}

Pusat Kajian Pengurusan Pembangunan Islam (ISDEV), Universiti Sains Malaysia, Pulau Pinang.

*Corresponding author: shafiehusna@gmail.com

\begin{abstract}
During Tun Dr. Mahathir Mohamad served as a Prime Minister of Malaysia, some efforts are shown when he trying to evaluate the current economic system which is based on the conventional economic system and trying to change to the Islamic economic system. This is caused by the evolution from the westernized thought to the Islamic thinking that occurred by a paradigm shift of people who was more interested in switching to the Islamic economic system. However, it's weird because this thought is differ from Tun Dr. Mahathir Mohamad's leadership who is deemed to be more westernized than Islamic ways. In the meantime, Tun Dr. Mahathir Mohamad also had implemented the Dasar Penerapan Nilai-nilai Islam policies and he had declared Malaysia as an Islamic state. The problem is, the economic development is mixed between the conventional economic development and the Islamic economic development. It is being an issue because when the people are taught to use the Islamic economic system? Is that the outcome from the implementation of the Dasar Penerapan Nilai-nilai Islam by Tun Dr. Mahathir Mohamad's leadership? What are the Islamic economic criteria has been used by Tun Dr. Mahathir Mohamad to attract the people? In order to answer the above questions, this paper was written to answer these questions by examining and analyzing the implications of the Tun Dr. Mahathir Mohamad's leadership in the Islamic economic development in Malaysia. The methodology has been used for this paper are using the literature review method and content analysis method. The results shows during Tun Dr. Mahathir Mohamad served as Prime Minister of Malaysia, he has been attempting to develop the Islamic economic system in Malaysia. Tun Dr. Mahathir Mohamad also approached the Saudi Arabia to get the information and an experience from their implementation economic system based on shari'ah. Interestingly, although the implementation of the Islamic economic system is already started in Malaysia, the positions of non-Muslims in the country are not affected at all
\end{abstract}

Keywords: Leadership; Tun Dr. Mahathir Mohamad; economic development; Islamic economic development Islam in Malaysia

\begin{abstract}
Abstrak
Semasa Tun Dr. Mahathir Mohamad berjawatan sebagai Perdana Menteri Malaysia, ada usaha untuk mengevaluasi sistem ekonomi semasa iaitu berkeinginan menilai semula sistem ekonomi konvensional untuk ditukar kepada sistem ekonomi Islam. Evolusi dari satu tahap pemikiran keBaratan kepada tahap pemikiran keIslaman berlaku berikutan anjakan paradiqma ketara masyarakat daripada berminat kepada ekonomi konvensional beralih kepada berkehendakkan ekonomi Islam. Ia sesuatu yang ganjil kerana pemikiran ini berbeza dengan cara kepimpinan Tun Dr Mahathir Mohamad yang disifatkan lebih keBaratan daripada keIslaman. Dalam pada itu, Tun Dr. Mahathir Mohamad pernah melaksanakan dasar Penerapan Nilai Islam dan pernah mengisytiharkan Malaysia sebagai sebuah Negara Islam. Masalahnya, perkembangan ekonomi tersebut bercampur aduk antara perkembangan pembangunan ekonomi konvensional dengan perkembangan pembangunan ekonomi Islam. Bila masanya masyarakat terdorong ke arah menggunakan ekonomi Islam? Adakah ia hasil implikasi kepemimpinan Tun Dr. Mahathir Mohamad secara tidak langsung dalam dasar Penerapan Nilai-nilai Islam? Apakah kriteria ekonomi Islam yang digunakan oleh Tun Dr. Mahathir Mohamad yang menarik minat masyarakat? Kertas kerja ini ditulis untuk menjawab persoalanpersoalan tersebut dengan meneliti dan menganalisis implikasi kepemimpinan Tun Dr. Mahathir Mohamad dalam pembangunan ekonomi Islam di Malaysia. Hasil menggunakan kaedah kepustakaan dan kaedah analisis kandungan didapati bahawa Tun Dr. Mahathir Mohamad semasa menjadi Perdana Menteri Malaysia telah berperanan dalam membangunkan ekonomi Islam di Malaysia. Tun Dr. Mahathir Mohamad telah berusaha mendekati negara Arab Saudi bagi mendapatkan maklumat dan pengalaman daripada mereka dalam pelaksanaan sistem ekonomi berlandaskan syariah. Menariknya, walaupun sudah bermula pelaksanaan sistem ekonomi Islam dalam institusi-institusi Islam di Malaysia, kedudukan golongan bukan Islam dalam negara tidak terjejas sama sekali.
\end{abstract}

Kata Kunci: Kepemimpinan; Tun Dr. Mahathir Mohamad; pembangunan ekonomi; pembangunan ekonomi islam di malaysia

(C) 2016 Penerbit UTM Press. All rights reserved

\subsection{INTRODUCTION}

Malaysia is the first country that introduced Islamic banking system in the South East Asia, under Tun Dr. Mahathir Mohamad's leadership, he started the Islamic economies system by establishing Bank Islam Malaysia Berhad in 1983 (Hassan, 2008:1). It was established in order to fulfill the financial needs of both Muslims and non-Muslims. According to Ibrahim (2003), the purpose of Bank Islam Malaysia Berhad at that time was to ensure that Malaysia lead and develop the Islamic financial system, thus enable to branch out from the existed conventional system.

However, the implementation of Islamic financial system by Tun Dr. Mahathir Mohamad at that time had caused a lot of confusion to the public. Some of questions that aroused were whether the Islamic economy system can mix with conventional economic 
system? What was the Islamic economy criteria used by Tun Dr. Mahathir Mohamad? What were the challenges of Islamic economies in Malaysia when Tun Dr. Mahathir Mohamad was associated with many conventional economic issues? To answer these three questions, this paper analyse the leadership implications of Tun Dr. Mahathir Mohamad on Malaysia's Islamic economies during his tenure as the fourth Prime Minister of Malaysia.

This article used descriptive qualitative research design which used library research as method to obtain secondary data. Subject determination method was used to focus on the field related to Islamic economic development. Lastly, method of content analysis was used to systematically observe and clarify the contents of the documents researched. This paper was then divided into two parts; Firstly, justification for the selection of Islamic economic system in Malaysia, and secondly analysis of the leadership implications of Tun Dr. Mahathir Mohamad on Malaysia's Islamic economy.

\title{
2.0 JUSTIFICATION OF ISLAMIC ECONOMIC SYSTEM IN MALAYSIA
}

The Islamic economy system in Malaysia began in the late 1950s when the country began to achieve independence by the establishment of baitul mal (treasury) in each country (Hassan \& Rahim, 2012: 1581). However, the existence of baitul mal still cannot fulfill the needs of the society in Malaysia, especially Muslims. According to Hassan and Rahim (2012), the awareness of the Muslim community to embrace Islam starting in the 1970s involving the economic, political and social realization. From the point of Islamic economy, Malaysia was managed to establish the first Islamic bank in the country, namely Bank Islam Malaysia Berhad that commenced its operations on July $1^{\text {st }}$, 1983 (Hassan, 2008; Faisal, 2013: 26).

Tun Dr. Mahathir Mohamad as founder, has introduced Bank Islam Malaysia Berhad in 1983 as a step towards the development of Islamic economies in the country. In the early days, Lembaga Tabung Haji Malaysia (TH) hold shares of Bank Islam Malaysia Berhad by 12.5 per cent, worth 80 million Ringgit Malaysia (RM) to enable the community to invest in bank which is based on Islamic banking system (Badawi, 2005: x). Then, there were also other banks that started to use Islamic financial system such as Bank Muamalat Malaysia Berhad. Even though Iran, Sudan and Pakistan were among the earliest countries to introduce Islamic financial system in the 1970s, but the Islamic financial system in Malaysia is recognized as more advanced compared to these countries that have been practicing the system for a long time (Dusuki, 2014: 170).

\begin{abstract}
"With the establishment of Bank Islam, we believe that the Muslim's economies and resilience and also Islam itself will become stronger. The Islamic financial system is a new mean to the financial system that it exists now".
\end{abstract}

(Mohamad, 2000)

Pandian (2005: 192-194) explained that by setting up Islamic banking institutions, other than strengthening the Tun Dr. Mahathir Mohamad's political influence, it can also help to improve the living standard of the Muslim community. It is because the existing conventional economic system was unable to meet the needs of the Muslim community. However, according Hassan and Rahim (2012), the authorities are still on the opinion that full replacement of conventional economic system with the Islamic economic system is not fair. In this regard, Malaysia is still simultaneously practicing the dual banking and financial systems, which are conventional financial system and the Islamic financial system. Through the dual system, now the Islamic financial system is operating in parallel with the conventional financial system. The Islamic financial system in the country also includes the Islamic banking system, interbank money market, Islamic insurance or takaful, Islamic capital markets and specialized financial institutions that provide alternative sources of financing (Bank Negara Malaysia, 2009: 200). According to Bank Negara Malaysia (2009), intertwined relationships between these components clearly proves that the Islamic financial system can increase the resilience and robustness of the Islamic financial system in the face of financial shocks and in turn can contribute to the stability of the Islamic financial system inside and outside the country.

The implementation of the Islamic economic system in Malaysia had faced challenges in Asian financial crisis in the year 1997 and 1998. Hakimi (2003) divided the challenges of the Islamic economic system in Malaysia into three phases. The first phase involved the $60 \mathrm{~s}$ and 70s that led to the problem of developing country economies in the Muslim community because of the economy of the Muslim community at that time was very reverse. According to him, Bank Negara Malaysia (BNM) is responsible for determining the country towards prosperity. In addition, BNM also play a role in driving economic growth, reduce the level of unemployment, eradicate poverty and restructure society (Bank Negara Malaysia, 2002). Obviously, Hakimi (2003) said that in implementing all these matters, the central bank should keep the national currency and in this phase of the economic system dominated by non-Muslims. Given the economic system dominated by non-Muslims, so people have to contend with the problem of usury. Next, the second phase will attempt to show the country's Muslim community to strengthen Islamic institutions. This is to assist in developing the Islamic economic system in the country and thus help in raising the economy of the Muslim community. Among them is the establishment of the first Islamic bank in Malaysia, Bank Islam Malaysia Berhad, the Islamic financial system has been offering various types of products such as takaful and protection of property rights (Pandian, 2005: 192). The financial crisis that occurred in 1997 and 1998 as well as the transformation of the country. In the field of economic, political and social, economic turmoil clear at that time had left a significant impact on the country and the implementation of the Islamic financial system was tested by the economic crisis at that time (Hassan \& Rahim, 2012; Shuib, 2014).

The third phase as classified by Hakimi (2003) was that the Muslims need to rethink about the affairs of the Islamic economic system in the country. This is referred to the value of Ringgit Malaysia (RM) at that time had been lost in value by 60 per cent, while other Asian countries such as Indonesia lost as much as 600 percent. Among the questions raised by him is what is the purpose of the real money according to Islam?' In the meantime, Tun Dr. Mahathir Mohamad as Prime Minister of Malaysia in the period of the crisis had made a phone call from Hong Kong to ban the trading of currency because the activities will worsen the economic situation (Mohamad, 1997). Also, the refusal from Tun Dr. Mahathir Mohamad at that to accept funding from the International Monetary Fund (IMF) had put the country a step forward in making changes towards currency and financial controlling that affects the monetary system in Malaysia (Mohamad, 1997; Mohamad, 2012). This step was taken by the state in controlling the RM shows the determination of the state to stabilize the currency and free from capitalism. 


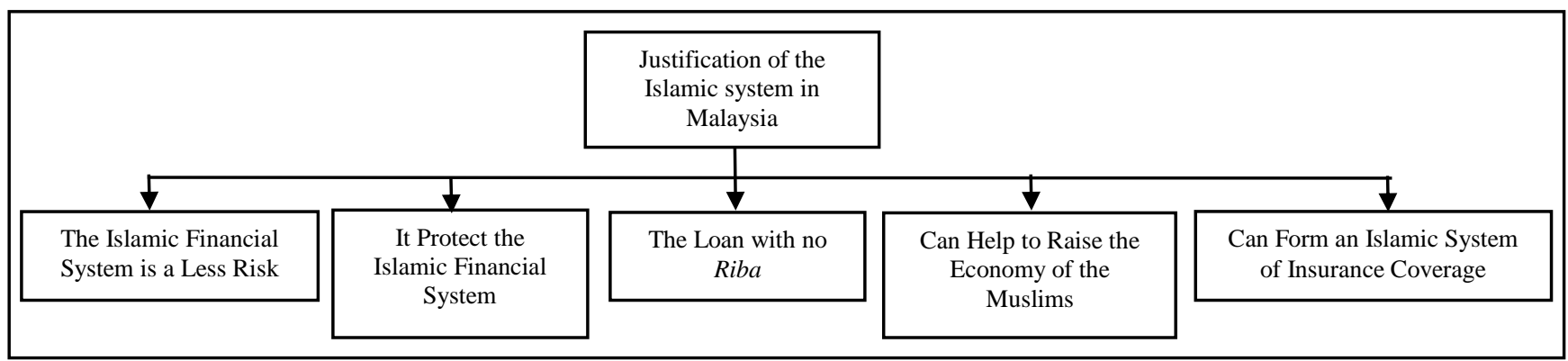

Figure 1 Justification of Islamic System in Malaysia

In the struggle of the global financial crisis, a state must find an answer by returning to the practice of the Islamic system. Islamic history clearly proved gold and silver as money that remains strong over the centuries not damaged no depreciation or cannot be printed again (Hakimi, 2003). Further, Hakimi (2003) said that the cancellation of banknotes RM 1000 and RM 500 was a very appropriate step in highlighting the dinar and the dirham. Also, the discussion was made to prevent other people from smuggling the money out (Mohamad, 2010; Mohamad, 2012: 802). The gold dinar (flakes of 22 carat gold weighing 25.4 grams) at that time is not more than RM 200. So with the cancellation, there is no more banknotes that have the value more than the dinar. Besides, the biggest banknote is only RM 100 . Next, Tun Dr. Mahathir Mohamad has suggested the further uses of gold dinar as currency for the trade business between the Muslim countries and as a national savings (Mohamad, 2010). As for Hassan and Rahim (2012), they argued that, in that time, it is the right time to the Muslim countries restructure and strengthen the Islamic financial system between them. At the same time, the responsible parties can shows the world that the Islamic financial system is the primary method as a way of global economic recovery. Moreover, according to them, the Islamic financial system is considered as less risky because it adopts the sharing of the profit and loss and they are also able to protect the Islamic financial system itself from the financial crisis.

Figure 1 explains on the justification of the Islamic system in Malaysia that can be summarized into five reasons. First, the Islamic financial system is less in risk; second, it protects the Islamic financial system; third, no riba with a loan; fourth, help raising the economy of the Muslims communities; and fifth, form an Islamic system of insurance coverage.

\subsection{THE IMPLICATIONS OF TUN DR. MAHATHIR MOHAMAD'S LEADERSHIP ON ISLAMIC ECONOMIC DEVELOPMENT IN MALAYSIA}

There are four implications of Tun Dr. Mahathir Mohamad's leadership on Malaysia's Islamic economic system. First, the leaders were tend to choose the Islamic economic system; second, the development of the Islamic economic system in Malaysia; Third, the adaptation of the Islamic economic system by non-Muslims communities; and fourth, the social empowerment through the Islamic economic system by Muslim society in Malaysia.

For the first implication, there are tendencies of leadership in Malaysia are called to implement the Islamic economic system. This propensity was caused by Tun Dr. Mahathir Mohamad's leadership, who also wanted to implement the Islamic economic system. It was described by Weber (1968) that the tendency towards an ideology is also caused by the power and the authority. Regarding to this trend, some consensus occured to decide and implement an Islamic economic policy in Malaysia (Abu Bakar, 2002). For instance, Tun Dr. Mahathir Mohamad approached the Saudi Arabia to get some information from those who have experience in implementing economic policy based on sharia (New Straits Times, December 8, 1980). In the meantime, Tun Dr. Mahathir Mohamad's seriousness to implement the Islamic economic system attracted the attention of the Saudi Arabian government thus, supporting Malaysia to fulfill on Islamic banking, to build the International Islamic University Malaysia (IIUM), resolve the issues related to Hajj, Umrah and also became a member of the Organization of Islamic Conference (OIC) (Idris, 2007:152-153).

Besides that, the second implication which affected the Islamic economics were refer to the Islamic economic system in Malaysia. This system is developed based on the Islamic banking and monetary system. As for the Islamic banking, there are two institutions that was established which is the Lembaga Tabung Haji Malaysia (TH) and Bank Islam Malaysia Berhad. Then, for the monetary system, the uses and the money exchange was proposed to change to the uses of dinar. The spirit to build this Islamic banking was enhanced when the TH was introduced in 1963 (Al-fattani, 2008: 408). It was founded during the reign of the second Prime Minister of Malaysia, Tun Abdul Razak. However, the Islamic banking system-was actually introduced when Tun Dr. Mahathir Mohamad became a Prime Minister in 1981. As a result, the Bank Islam Malaysia Berhad was introduced in 1983 (Khoo, 1995: 177-178). Regarding the successful implementation of the Bank Islam Malaysia Berhad, it had been an urge the public authorities to make another establishment of a bank that based on Islamic banking such as the Bank Muamalat Malaysia Berhad.

Moreover, since 1983 until September 2010, Bank Islam Malaysia Berhad now has more than 107 branches and 878 units of terminals around the country and also holds assets cost about RM30.3 billion in Islamic banking industry in Malaysia (Rating Agency Malaysia Berhad, 2010: 2). The result from the Islamic banking progress in Malaysia absolutely has attracted the attention of people in and outside of Malaysia. This progress also has made Malaysia now as one of the main hubs in the Islamic financial system development (Badawi, 2005; Ghazali, 2012).

Next, Tun Dr. Mahathir Mohamad also had proposed the country to use dinar in monetary exchange system between Muslim countries during the Asian financial crisis (1997-1998). The proposal was also based on the history of the Bretton Woods system in 1971 due to the high inflation rates and the instability value of the currency (Muhammad, 2011: 79). In finding a way to resolve the crisis, the 
uses of the gold dinar or Islamic economic system seen as a solution to replace the US dollars currency to gold dinar which definitely has the stable unit (Muhammad, 2011; IMF, n. d). Consequently, because of that Tun Dr. Mahathir Mohamad suggested the uses of the dinar in international trade to replace the US Dollar (Abu Bakar, 2002; Salamon \& Hussain, 2010; Dali \& Razak, 2013: 1272). In referring to the idea that had been proposed to change existing currency to the dinar, it is shows very clear that Tun Dr. Mahathir Mohamad wants the Islamic economic system to replace the existing economic system. Besides, according to The Gold Dinar Research Group (2001) and Hakimi (2003), the uses of gold and silver coins as a monetary exchange can serve the currency to remain more stable. It is because of the value of the dinar and silver as a currency has proven to remain strong. Apart of that, the dinar and silver also had proved their value does not suffer depreciation, cannot be printed and are not easily damaged.

In addition, the gold dinar is also intended to be used as a currency of its business exchange. This is because Malaysia is considered as an open country and vulnerable to the volatility in the foreign exchange (Mohamad, 2010; Dali \& Razak, 2013). Furthermore, the proposal to use the gold dinar by Tun Dr. Mahathir Mohamad is also looking at the uses of the gold dinar that could be unifying between the Muslim countries in terms of strengthening their Islamic economics as strong as a value over the time (Mohamad, 2003).

Then, Tun Dr. Mahathir Mohamad also refused to borrow a fund from the IMF during the Asian financial crisis (1997-1998). With the decisions made from that, at that time Malaysia is seen as a model country in a controlling currency system without involving riba. Tun Dr. Mahathir Mohamad said that Malaysia does not need to borrow a fund from the IMF because the country will not be affected by the debt and the country's debt at that the time has already repaid (Mohamad, 2012: 797). Hence, the step are taken by Tun Dr. Mahathir Mohamad in controlling the national currency showed his determination to make the national currency independent from the capitalism and make the country safe from economic experts organizations such as the IMF. Apandi and Shariffuddin (2007:244) said, the results are clearly shows when Malaysia does not want to receive IMF assistance because the funds will give along with IMF conditions that are pro-Western and ultimately the borrowers will accept more impacts from the negative sides. For Dusuki (2014), he acknowledged that Malaysia today is known as the pioneer of the Islamic financial system which is one of the comprehensive country in the world. In fact, according to him, Malaysia has grown rapidly in terms of Islamic economy and Islamic finance and has more than 30 units banking institutions based on Islamic principles to provide a way out to the communities in choosing a system guided by the shari'ah.

Next, the third implication is the adaptation of the Islamic economic system from the non-Muslims communities in Malaysia. The realignment of the existing economic system to a dual economy system which is including the Islamic economic system by Tun Dr. Mahathir Mohamad had caused unease among the non-Muslims in Malaysia. In Ghazali (2012) discussion, according to Yong in 2003, its seen as an attempt to implement the agenda of Islam under the secular constitution that has been believed by the non-Muslims before this. But, despite fears to be felt by the non-Muslims in Malaysia, due to the implementation of the Islamic economic system, Tengku Razaleigh Hamzah has been voiced the guarantee of the welfare for the non-Muslims but also the implementations will give them more chances and benefits to them. It was stated in Utusan Malaysia, 1983 that in 1982, when tabling the Rang Undang-undang in the Dewan Rakyat, Finance Minister, Tengku Razaleigh Hamzah explained that the position of the non-Muslims in Malaysia will not be affected in the development of Islamic institutions. In fact, the implementations also allow the non-Muslims in Malaysia to get benefit for more because Islam is a universal religion to all people.

The fourth implication is the social empowerment through the Islamic economic system in Muslims society in Malaysia. There are four social impacts of the Islamic economic system at the time of Tun Dr. Mahathir Mohamad's leadership. First, economic strengthening between the Muslims communities; second, the changing landscape of education systems; and third, the impact on the image of Tun Dr. Mahathir Mohamad as the statesman. For the first impact, the implications of the development of the Islamic economic system towards economic strengthening between the Muslims communities. According Ghazali (2012: 94), the strengthening of the economic system was happened through the establishment of the Bank Islam Malaysia Berhad. It is seen as a way to strengthen the economy and becoming the resilience of the Muslims community in the country. Mohamad (2012) stated that the economy of the Muslims community in Malaysia should be strengthened to ensure that the Muslim community in Malaysia can become more stable and stronger from the economic sides because the majority of people in this country are Muslims.

Besides that, the second impact shows the establishment of educational institutions can also be seen as a growing trend from Tun Dr. Mahathir Mohamad's leadership in Islamic economic system in Malaysia. The establishment of the education centre such as the International Islamic University Malaysia (IIUM), Universiti Sains Islam Malaysia (USIM) and the Institute of Islamic Understanding Malaysia (IKIM) has been made this mega projects being a changes in the Islamic economic system in Malaysia (Ghazali, 2012). According to Ahmad (2007: 31), the establishment of these institutions is to prove that Islam was not separated from the temporal development and the modernization. Ghazali (2012) also have a view that the establishment of these institutions that also to provide a place for students to learn and understand Islam in their own country. In fact, an introduction to a subject of Islamic civilization in all the local universities are applied to ensure that the young people has sacred the knowledge in their learning process and also the subject can be a foster to a closer relationship among the races in Malaysia.

Besides, the Islamic scholars are not only experts in their expertise fields but also they could learn and deepen their knowledge in the Islamic studies. Thus, knowledge of the period can be attributed to the religion and can provide a strong believe to the divine (Mohamad, 2005: 201). This can be attributed when Tun Dr. Mahathir Mohamad said that the establishment of the IIUM has its own goals in developing the Islamic thought in Malaysia (Khoo, 1995:176; Utusan Online, 2002). Tun Dr. Mahathir Mohamad also said the idea of the establishment of this institution is because the Islamic universities abroad are only emphasize the purely religious aspects of Islam while studying without learning and absorbing the other disciplines of knowledge. Moreover, according to Tun Dr. Mahathir Mohamad, all Muslims need to master in all fields of knowledge in addition to prepare them for the Muslims development and with that, they will able to reach the fullness of life and happiness (Ibrahim, 2002: 14-15).

Therefore, IIUM was established to generate the modern knowledge in accordance with the principles and objectives driven by Islam itself. In fact, according to Khoo (1995: 193), the initial idea or concept to build the IIUM in 1977 was the result from discussions in the seminar that was held in Makkah, Saudi Arabia and the construction financing of the institutions also was sponsored by members of the OIC. Moreover, an interviews Idris (2007: 153-154) with Prof. D. Sano Koutoub Moustafa who is an experts in International Fiqh Academy of the OIC said, the good relationship with the government of the Saudi Arabia indirectly helped the country to get the financial 
aid. Besides, financial assistance also had been provided during the year to Malaysia in the continuing survival of the Islamic institutions such as the IIUM, missionary bodies in the country and also religious schools in Malaysia.

Finally, social impact from the growth and development of the Islamic economic system in Malaysia had also improved the image of Tun Dr. Mahathir Mohamad in the eyes of many people who previously accentuate him towards hatred to Islam. Tun Dr. Mahathir Mohamad said that he had the liberal views and has only the tolerance in religious matters. Even so, Tun Dr. Mahathir Mohamad remained firm and consistent whenever he expressed his thought of Islam (Ahmad, 2007; 31).

\subsection{CONCLUSION}

Overall, the leadership of Tun Dr. Mahathir Mohamad had been proven that there is transformation towards the implementation of the Islamic economic system as compared with the previous leadership when he serves Malaysia as a Prime Minister. The implications of Tun Dr. Mahathir Mohamad's leadership of Malaysia's Islamic economic system can be divided into four implications. First, there are leaders tend to Islamic economic system; second, the development of the Islamic economic system in Malaysia; Third, the adaptation of the Islamic economic system in the non-Muslim communities; and fourth, social empowerment through the Islamic economic system on Muslim society in Malaysia.

For the first implication, it clearly shows the tendency of Tun Dr. Mahathir Mohamad's leadership who want development of the Islamic economic system which can be developed through the ownership of power. The second implication shows the impact on the development of the Islamic economic system in Malaysia comes along with the development of the first Islamic bank, Bank Islam Malaysia Berhad operated in 1983. The consequences with the Islamic economic system increasingly with the establishment of other Islamic banking institutions such as Bank Muamalat Malaysia Berhad. The development of the Islamic economic system in the country also continued with the commitment of Tun Dr. Mahathir Mohamad, who proposed the uses of gold dinar to face off the Asian financial crisis (1997-1998). The clear rejection shown by Tun Dr. Mahathir Mohamad proved that he was trying to avoid the element of riba in Malaysia's economic system to strengthen the Islamic economic system in Malaysia.

Next, the research in the third implication, the effects of a shift in the Islamic economic system under the leadership of Tun Dr. Mahathir Mohamad also was protected the interests and welfare of the other races in Malaysia to ensure their economies are become stronger with the implementation of the Islamic economic system. Finally in the fourth implication of the development of the Islamic economic system in Malaysia can be divided into three implications. First, the strengthening of the Muslim's community economy; second, the changing of the landscape of education system; and third, the impact on the image of Tun Dr. Mahathir Mohamad as the statesman. The development of the Islamic economic system in Malaysia also indirectly strengthen the Muslim's economy while they are also get much more benefits from the establishment of educational institutions in Malaysia.

\section{Acknowledgement}

We are grateful to Allah SWT for giving us opportunity to write this paper successfully. We are very thankful to all lecturers, departmental heads, officials and also all office staffs of The Centre for Islamic Development Management (ISDEV) for giving us support, valuable advice and endless inspirations to finish this paper.

I would like to give an appreciation to Dr Mohd Syakir Mohd Rosdi as a senior lecture at ISDEV, USM. He is a member of the Research University Team (RUT) Grant, ISDEV, Universiti Sains Malaysia, which is based on the theme 'Islamic-Based Development' (1001/CISDEV/856001). This working paper in part of an in-depth research related to the Grant. I am very thankful for his time and willingness to cooperate with me throughout writing this article. His advice and guidance was very much appreciated.

\section{Reference}

Ahmad, A. M. (2007). Pemikiran Tun Dr. Mahathir Mohamad. Penerbit Universiti Malaya, Kuala Lumpur.

Ahmad, R. (2004). Pemikiran Tun Dr. Mahathir Mohamad. Melaka: Institut Kajian Sejarah dan Patriotisme Graha (IKSEP).

Ahmad, S. H. (2003). Mahathir Pencetus Tamadun Insaniah. Juz' Art, Kuala Lumpur.

Akhir, N. H. M. (2004). Penyelesaian Masalah Kejatuhan Mata Wang: Perbandingan Pendekatan Ekonomi Konvensional Dengan Ekonomi Islam. Submitted thesis in partial fulfilment of the Master Degree of Universiti Malaya.

Al-Fattani, W. S. W. Y. (2008). Malaysian Experiences on the Development of Islamic Economics, Banking And Finance. King Abdul Aziz University, Islamic Economic Institute, 405-417.

Apandi, L. S. A., \& Shariffuddin, M. D. K. (2007). Islam, Kestabilan Politik Dan Ekonomi: Kejayaan Malaysia. Kuala Lumpur: Penerbit Universiti Malaya.

Badawi, A. A. (2005). Menggapai Kecemerlangan Sebuah Negara Islam. In A. A. Badawi, M. Mohamad, \& M. H. Kamali (Eds.) Malaysia Sebagai Sebuah Negara Islam, vii-xiv. Kuala Lumpur: Institut Kefahaman Islam Malaysia (IKIM).

Bakar, M. A. (2002). Polemik Negara Islam Dan Pembudayaan Politik Malaysia. Institut Perkembangan Minda, Selangor.

Bank Islam Malaysia Berhad. (2003). Credit Rating Rationale. Bank Islam Malaysia Berhad, Kuala Lumpur.

Bank Negara Malaysia (BNM) (2002). The Malaysian Economy in 2002. Bank Negara Malaysia, Kuala Lumpur.

Bank Negara Malaysia (BNM) (2003). Sistem Kewangan Islam. Bank Negara Malaysia Publication, Kuala Lumpur.

Bank Negara Malaysia (BNM) (2009). Buku Suku Tahunan Suku Keempat 2009. Bank Negara Malaysia, Kuala Lumpur.

Dali, S. Z. M., \& Razak, N. A. (2013). Implementation Gold Dinar: Is It Feasible?. Prosiding PERKEM VIII, 3, 1272-1279.

Dusuki, A. W. (2014). Politik Islam Dan Melayu. Yayasan Dakwah Islamiah Malaysia (YADIM), Kuala Lumpur.

Faisal, L. (2013). Politik Ekonomi Islam Dalam Pembangunan Ekonomi Nasional Di Indonesia. Indonesian Publication Index, 5(2), 117-128.

Ghazali, M. R. (2012). Pembangunan Islam Di Malaysia Dalam Era Mahathir. Penerbit Universiti Sains Islam Malaysia (USIM), Negeri Sembilan.

Hakimi, I. (2003). Ekonomi Islam Pengalaman Malaysia. Retrieved from http://web.usm.my/dinar/article/GDRG\%20MedanSem\%20Ekon\%20Islam.htm

Hassan, N. M., \& Rahim, S. R. M. (2012). Keupayaan Menampak Kejutan Dan Krisis Ekonomi: Analisis Perbandingan Perbankan Islam Dan Konvensional. Prosiding PERKEM VII, 2, 1581-1591.

Hassan, Z. (2008). Perlaksanaan Sistem Perbankan Islam Di Malaysia: Perspektif Undang-Undang. Retrieved from https://zulkiflihasan.files.wordpress.com/2008/06/book-usim-1.pdf 
Hilley, J. (2009). Malaysia: Mahathirisme, Hagemoni Dan Pembangkang Baru, terj. PTS Publications. Institut Terjemahan Negara Malaysia Kuala Lumpur, Kuala Lumpur.

Ibrahim, H. (2003). Ekonomi Islam. Pengalaman Malaysia. Diakses daripada Laman Web Rasmi The Gold Diner Research Group, Universiti Sains Malaysia. Retrieved from http://web.usm.my/dinar/article/GDRG\%20MedanSem\%20Ekon\%20Islam.htm

Ibrahim, I. (2002). Pemikiran Dr. Mahathir Tentang Islam. Utusan Publications \& Distributors Sdn Bhd, Kuala Lumpur.

Idris, A. (2008). Malaysia's Relations With Saudi Arabia Under Tun Dr. Mahathir Mohamad Era, 1981-2003. Connecting Respositories (CORE), 143-158.

International Monetary Foundation (IMF) (2003). Apakah Dana Moneter Internasional (IMF)? Washington D.C., Amerika Syarikat.

Ismail, M. Z., Roslan, A., Mohamad, M. T., \& Ahmad, N. H. (2015). Perbankan Islam di Malaysia: Tinjauan Strategi Pengukuhan. Labuan e-Journal of Muamalat and Society, 9, 48-56.

Jamalie, Z. (2011). Analisis Pemikiran Mahathir Mohamad Mengenai Islam Dan Pelaksanaan Dasarnya Dalam Negara Malaysia. Submitted thesis in partial fulfilment of the Doctor of Philosophy of Universiti Malaya.

Khoo, B. T. (1995). Paradoxes Of Mahathirism. An Intellectual Biography Of Mahathir Mohamad. Oxford University Press, Kuala Lumpur.

Markom, R., \& Ismail, N. (2009). The Development Of Islamic Banking Laws In Malaysia: An Overview. Jurnal Undang-Undang Dan Masyarakat, Universiti Kebangsaan Malaysia, 13, 191-205.

Mohammad, M. (1997). Koleksi Ucapan Mahathir 1995-1996. Jabatan Penerangan Malaysia, Kuala Lumpur.

Mohamad, M. (2000). Islam and the Muslim Ummah Selected Speeches, 2. Putrajaya: Pelanduk Publications Sdn Bhd for Prime Minister's Office of Malaysia.

Mohamad, M. (2002). Reflections On Asia. Pelanduk Publications, Selangor Darul Ehsan.

Mohamad, M. (2005). Ensiklopedia Mahathir Mohamad. 1. Darul Fikir. Kuala Lumpur,

Mohamad, M. (2010). Dinar Emas 2. Retrieved from http://chedet.cc/?p=463

Mohamad, M. (2012). Doktor Umum. Memoir Tun Dr Mahathir Mohamad. MPH Group Publishing Sdn Bhd, Kuala Lumpur.

Muhammad, N. M. N. (2011). Public Acceptance Towards Kelantan Gold Dinar. Universiti Teknologi Mara Institutional Respository, Business And Management Quarterly Reviee, 3, 79-87.

Pandian, S. (2005). Legasi Mahathir. Kuala Lumpur: Utusan Publications \& Distributors Sdn Bhd.

Rating Agency Malaysia Berhad (2010). Bank Islam Malaysia Berhad Financial Institutional Ratings. Kuala Lumpur: Rating Agency Malaysia Berhad.

Salamon, H., \& Mustafa, Z. (2010). Pelaksanaan Dinar Dalam Sistem Ekonomi Moden: Cabaran Dan Prospek Masa Depan. E-Muamalat Portal Rasmi Muamalat Dan Kewangan Islam, 131-148.

Shuib, M. S. (2014). Konsep 'Mahathiriskonomisme': Sorotan Memperkukuh Kedaulatan Ekonomi Islam Dalam Kajian Krisis Ekonomi 1997/1998. Jurnal YADIM, 9 (1), 157-178.

The Gold Dinar Research Group (2001). Perkenal Semula Dinar Islam Beransur-Ansur. Retrieved from Laman Web Rasmi The Gold Diner Research Group, Universiti Sains Malaysia http://web.usm.my/dinar/article/GDRG\%20Perkenal\%20Dinar\%20Islam.htm

Utusan Online (2002). Wujudkan Badan Retrieved Cendekiawan, http://ww1.utusan.com.my/utusan/info.asp?y=2002\&dt=0131\&pub=Utusan_Malaysia\&sec=Muka_Hadapan\&pg=mh_06.htm

Webber, M. (1968). On Charisma And Institution Building. University Of Chicago, London. 